doi: 10.12957/ childphilo.2019.44574

\title{
following philosophy with children concepts in practice of teacher education
}

\author{
arie kizel 1 \\ university of haifa, israel \\ orcid id: https:/ / orcid.org/0000-0002-9352-3120
}

abstract

Teacher-student dialogue plays a central role in facilitating the ongoing growth of those engaged in education, particularly dialogue that invites student reflection on the instruction being given and the teacher herself. Dialogue should aid students in articulating self-awareness (conscious or unconscious) regarding their behaviour and learning habits and the learning process and its results at the same time as assessing their quality and the ways in which they may be improved. One of the reasons behind our increasing inability to break down the inherent barrier between teachers and students is due to a lack of engagement in ongoing dialogical reflection as a means of advancing the teaching-learning process within the school. This article offers a theoretical contribution on dialogue in teacher education through the philosophical concepts of a ten years of teacher education program which was designed according to the principals of Philosophy with Children. The program fostered creativity and self-reflective thinking in teacher education and offered dialogical methods. It is based also on six dimensions that are the basis of Philosophy with Children: learning from a place of questions, community of learning that resists the educational hierarchy that boasts of omniscience, coordinator as a participant in the learning process, learning in the real present, legitimization of improvisation as a way of learning, learning as liberating the learner from disciplinary boundaries. All six dimensions view Philosophy with Children as a pedagogy of searching at whose center lies the pursuit of meaning that facilitates personal development-and thus self-direction and capability.

keywords: philosophy with children; teacher education; pedagogy of reflection; dialogue

\section{seguindo conceitos da filosofia com crianças na prática de formação de professores}

\section{resumo}

O diálogo professor-aluno desempenha um papel central em facilitar o crescimento contínuo dos envolvidos na educação, particularmente o diálogo que convida a reflexão do aluno sobre a instrução dada e o próprio professor. O diálogo deve ajudar os alunos a articular a autoconsciência (consciente ou inconsciente) sobre seus comportamentos e hábitos de aprendizagem, o processo de aprendizagem e seus resultados ao mesmo tempo em que avalia sua qualidade e as maneiras pelas quais elas podem ser melhoradas. Uma das razões por trás de nossa crescente incapacidade de romper a barreira inerente entre professores e alunos é devido à falta de engajamento na reflexão dialógica em andamento, como forma de fazer progredir o processo de ensino-aprendizagem na escola. Este artigo oferece uma contribuição teórica sobre o diálogo na formação de professores através dos conceitos filosóficos de um programa de dez anos de formação de professores, elaborado de acordo com os princípios da Filosofia com Crianças. O programa promoveu a criatividade e o pensamento auto-reflexivo na formação de professores e ofereceu métodos dialógicos. Baseia-se também em seis dimensões que são a base da Filosofia com Crianças: aprender a partir de um lugar de perguntas, comunidade de aprendizagem que

1 E-mail: ak@akizel.net 
resiste à hierarquia educacional que se orgulha da onisciência, coordenador como participante do processo de aprendizagem, aprendendo no presente real, legitimação da improvisação como forma de aprender, aprendendo como libertando o aprendiz das fronteiras disciplinares. Todas as seis dimensões veem a Filosofia com Crianças como uma pedagogia da busca em cujo centro está a busca de significado que facilita o desenvolvimento pessoal - e, portanto, o auto-direcionamento e capacidade.

palavras-chave: filosofia com crianças; formação de professores; pedagogia da reflexão; diálogo

\section{siguiendo a los conceptos de filosofía con niños en la práctica de la formación docente}

resumen

El diálogo profesor-alumno desempeña un papel central para facilitar el crecimiento continuo de quienes participan en la educación, en particular el diálogo que invita a los alumnos a reflexionar sobre la instrucción que se imparte y la propia maestra. El diálogo debe ayudar a los estudiantes a articular la autoconciencia (consciente o inconsciente) con respecto a su comportamiento y hábitos de aprendizaje y el proceso de aprendizaje y sus resultados al mismo tiempo que evalúa su calidad y las formas en que pueden mejorarse. Una de las razones detrás de nuestra creciente incapacidad para romper la barrera inherente entre maestros y estudiantes se debe a la falta de participación en la reflexión dialógica continua como un medio para avanzar en el proceso de enseñanza-aprendizaje dentro de la escuela. Este artículo ofrece una contribución teórica sobre el diálogo en la formación docente a través de los conceptos filosóficos de un programa de formación docente de diez años que fue diseñado de acuerdo con los principios de Filosofía con niños. El programa fomentó la creatividad y el pensamiento autorreflexivo en la formación docente y ofreció métodos dialógicos. Se basa también en seis dimensiones que son la base de la filosofía con niños: aprender desde un lugar de preguntas, una comunidad de aprendizaje que resiste la jerarquía educativa que se jacta de la omnisciencia, coordinador como participante en el proceso de aprendizaje, aprender en el presente real, legitimación de la improvisación como una forma de aprender, aprendiendo como liberando al alumno de los límites disciplinarios. Las seis dimensiones ven la filosofía con niños como una pedagogía de búsqueda en cuyo centro se encuentra la búsqueda de un significado que facilite el desarrollo personal y, por lo tanto, el autodireccionamiento y capacidad.

palabras clave: filosofía con niños; formación docente; pedagogía de la reflexión; diálogo. 
following philosophy with children concepts in practice of teacher education

\section{introduction}

A lack of engagement in ongoing dialogical reflection as a means of advancing the teaching-learning process within the school is one of the reasons behind our increasing inability to break down the inherent barrier between teachers and students. Teacher-student dialogue plays a central role in facilitating the ongoing growth of those engaged in education, particularly dialogue that invites student reflection on the instruction being given and the teacher herself. Dialogue should aid students in articulating self-awareness (conscious or unconscious) regarding their behaviour and learning habits and the learning process and its results at the same time as assessing their quality and the ways in which they may be improved.

This article offers a theoretical contribution to the discussion about the importance of integrating the philosophical-educational concepts of Philosophy with Children integrated in a ten-year program of teacher education at the University of Haifa's faculty of education. This program was based on pedagogy of dialogue and reflection $-\mathrm{a}$ framework that develops and empowers university's students by engaging them in a process of continual improvement responding to diverse situations, providing stimuli for learning, and giving anchors for mediation on the basis of the concepts of Philosophy with Children which were implemented into an adults teacher educations' program.

The pedagogy of dialogue and reflection relates, in this case, is based on the view that reflective dialogue forms one of the best ways in which students' learning needs can be identified and understood, the dialogic partnership between teacher and student facilitating the latter's ability to assess their 'real' level of knowledge and reach and exceed their potential in every stage of the learning process. The pedagogy of dialogue and reflection was employed during the preservice teacher-education period, students training to become middle and high school teachers doing their practica in schools in dialogical communities while 
simultaneously taking university courses to deepen and broaden their theoretical and disciplinary knowledge.

\section{pedagogy of dialogue and reflection in the teacher-education context}

The idea of partnership between teacher-education institutions and schools was further established in the United States in the wake of a series of longitudinal studies by John Goodlad and his colleagues in the 1990s. Examining American elementary and high schools (Goodlad, 1984) and 1,300 teacher-training programmes (Goodlad, 1994), the principal conclusion these studies reached was that both the school system and teacher-training programmes required revision. One of the primary suggestions made was that teacher-training students should gain experience in schools with an outstanding academic and educational record to which they would naturally return to teach upon graduation (Goodlad, 1990; Sirotnik, 2001). Although the coining of the term 'professional-development schools' by the Holmes Group in 1986 formed the conceptual framework for the idea of partnership, its implementation was relatively slow. By the beginning of the 1990s, however, hundreds of PDS schools had been established across the US, their number reaching more than a thousand in 1998 in 47 states. One of the important stages in the development of the PDS concept was the National Council of Accreditation of Teacher Education's introduction of a set of standards in 1998 (Levine, 2001).

While Israeli universities have clung conservatively to the old model of the teacher as trainer, the Israeli education system also adopted a programme of partnership with schools a decade ago with the aim of establishing a teachertraining curriculum integrating a practicum. Generally established between teacher-training colleges (also known as colleges of education) and (middle and elementary) schools, the idea was to promote connections and links between the two cultures (Zilberstein, Ben Perez, \& Grienfeld, 2006). It is preeminently exemplified in the creation of learning communities that seek to engender teaching-learning situations in which theory deepens understanding and insights into classroom teaching and pedagogy. 
This article aims to describe the way that the concept of pedagogy of dialogue and reflection was introduced into the teacher-education track at the University of Haifa (Israel) based on the principals of Philosophy with Children. The model seeks to cultivate the teacher-training student's ability to integrate various types of knowledge - practical and theoretical - within the framework of a dialogical learning community composed of teacher-training faculty and educational teams from field-training schools. At its base lies the view that teaching is a practical-reflective profession, students regarding the school as a place of learning and coming to affirm its value based on their recognition of the contribution assignments make to their own developments and society in general (Marshall, 1990). Enriched by the pedagogy of dialogue and reflection, the educational-intellectual atmosphere in such an environment can develop into a vibrant and dynamic space fostering intellectual tension and the sense of innovation and creativity that are so necessary for the educational task. The pedagogy of dialogue and reflection in a dialogical community further expands the mentoring teacher's role, making teacher-trainees part of a community of school teachers who are intimately involved in their training and ongoing education with the express intent of making them part of their community in particular and the education system in general. The main goal is that these teachers-students will, later in schools, will practice dialogical tools with their students.

\section{the pillars of dialogical-reflective model}

The fundamental premise of the model of this teacher education program is that proper reflective dialogue between teacher and teacher-students rests on three pillars. The first is the legitimization of the personal view of each of the partners in the dialogue combined with sensitivity to difference, empathy, mutual respect, and openness in their dialogical processes during the period that the teacherstudents is learning the profession in the work place (schools). Thus, for example, a teacher-training student and his teacher openly and non-judgmentally share with one another their views regarding their strengths and weaknesses. Meaning, 
both need to practice equality (in opposite to the conservative model of teacher education where usually the teacher enjoys a priority in his hierarchical professional status). This principle plays an important role in the accord between students and teachers regarding the level of the former's knowledge of their behaviour as a launching point for future improvement, the real and imagined influence of the factors that interfere with their learning processes, and the ways to discern these and reduce their influence.

The second pillar is joint analysis of the possible ways of coping with a certain professional situation, choosing options, and focusing on solutions and outcome. This principle reflects both the students' commitment to adopting successful methods and consequent achievements and the teacher/school system's commitment to provide feedback in a priori defined periods of time in order to help the students improve their work habits and results.

The third pillar is the use of metacognitive thought, at the heart of which lies students' practices of thinking about their thought processes on the basis of the assumption that the more they are aware of the various elements that influence their understanding the more they will be able to identify successful strategies and monitor them, thereby increasing their knowledge and improving their ability to solve problems. The metacognitive element is thus designed to contribute to enhancing students' personal responsibility and autonomy as learners and their awareness of the improvement process.

Implemented in teacher education, this model perceives teacher-training students as needing to think about their classes, students, and above all themselves as reflective professionals in a new way which combines also philosophical aspects about their profession. This is an important point in light of the fact that many students from multicultural backgrounds have never experienced dialogical and reflective teachers prior to their teacher-training studies. Responsible for the introduction of the concept of pedagogical content knowledge, Shulman's (1986) work led to the development of a school of thought that sought to identify teachers' knowledge of their subject matter and the 
importance of this for successful teaching. Reflective pedagogy adds a further component to this approach, placing at its centre the process constructed in the philosophical community of learners. From this perspective, the latter "can be regarded as having a worth independent of its benefit [...] Someone who values truth in this may find the constant effort to free his mind from prejudice and error painful" (Peters, 1996, p. 100). The model seeks to form a community of learners that engages in reflective dialogue when confronting an educational situation as a text presented during class discourse or the teacher-training group. As Gadamer (1999) suggests, a group of peers should listen carefully, without rushing to judgment. Or as Lipman, Sharp, \& Oscanyon observe, "Philosophy is [...] of enormous benefit to persons seeking to form concepts that can effectively represent aspects of their life experience" (1980: 90).

According to the program, this professional community of learners is based on the philosophical writings of Matthew Lipman, the father of Philosophy for Children, and in particular his ideas regarding the search for meaning. It frames the dialogue - in this case teacher education - within of six dimensions of teacher education (Kizel, 2016). The first dimension places learning from a place of questions rather than a corpus of answers at its centre. The second focuses on a community that facilitates a form of learning that resists the educational hierarchy that boasts of omniscience. The third places the coordinator as a participant in the learning process rather than as a "judge." The fourth sets learning in the (real) present against learning for the (unknown) future. The fifth legitimizes improvisation as a way of learning in place of predetermined content. The sixth regards learning as liberating the learner from disciplinary boundaries. All six dimensions view the group as a community of professional inquiry. In addition, the group's action is based on the concepts of Philosophy with Children as a pedagogy of searching at whose centre lies the pursuit of meaning that facilitates personal development - and thus self-direction and capability. This stands in stark contrast to the pedagogy of fear (Kizel, 2016a) that makes perpetual demands on the learner, induces apprehension about taking risks, reduces her competence, and 
creates a constant need for an omniscient "guide" that is so prevalent within traditional learning settings.

The principles of pedagogy of dialogue and reflection are based on the ideas propounded by Nelson (1949). Emphasizing the importance and power of dialogue in group learning, Nelson asserted that each group member may serve as a 'midwife' during the process of developing ideas, the goal of the dialogic process being to advance an idea from 'birth' to educational practice, truth being identified through consensus. Nelson's theory was expanded into the domain of teachertraining by one of his students, Gustav Heckmann (1981).

Dialogue in the context of group learning-including teacher-training education based on this model-and a community of learners adopts four elements from this approach and from Philosophy with Children's concepts:

(1) The importance of producing results. Ultimately, the dialogic process seeks to answer the philosophic question posed by eliciting the truth about the nature of worldviews regarding tolerance, freedom, justice, and responsibility;

(2) The importance of participation. Taking part in the collaborative process involves looking for answers to questions and developing a mutual understanding of others. Members share their concrete experiences, some of which the group selects for detailed investigation, all the members participating in the subsequent discussion;

(3) The importance of enriching an individual's deep understanding and enabling the participants to grasp the moral complexities of everyday life;

(4) The importance of dialogue as a practice in shaping educational life achieve. Dialogue leads to greater clarity regarding which acts are guided by educational thought and which are not, thereby enhancing the participants' confidence and enabling them to draw appropriate conclusions regarding the desired approach to an educational/educative life.

Here, the distinction between the 'act-of-talking' and the 'act-of-dialogue' is relevant, the latter involving investigation, risk-taking, and the preservation of equality (Alro \& Skovsmose, 2004, p. 15). As these authors remind us, the dialogic 
process being collective, it facilitates critique and thus serves as a tool for achieving meaningful learning. This form of dialogue calls for participants in interactions to respond to the other participants in a way that takes into account how they think other people are going to respond to them. According to William Isaacs (1999), it contains at least five components which were also at the heart of the teacher education program:

1. Respect: Partners in a dialogue should assume that all the participants are equal, legitimate, and important to the learning process -irrespective of whether or not you agree with their views.

2. Listening: Partners in a dialogue should listen for understanding and learning rather than correctness. They should be aware of their listening to others by paying attention to 'mental models' and obstacles that get in the way of what is being said and heard. The goal is not to listen in order to respond or advocate but to listen in order to understand.

3. Suspension of judgment: Partners in a dialogue should be aware of assumptions and certainties and learn to hold them apart or to the side without feeling compelled to act upon them.

4. Freeing oneself: Partners in a dialogue should seek to balance inquiry and advocacy, freeing themselves from rigid mindsets. Inquiry is an opportunity to seek clarification and a deeper level of understanding rather than to expose weakness.

5. Communicating one's reasoning process: Partners in a dialogue should talk about their assumptions and how they arrive at what they believe, endeavouring to identify the data on which they are based and engaging in the same process with respect to others.

As Peter Senge notes,

Dialogue is not merely a set of techniques for improving organizations, enhancing communications, building consensus, or solving problems. It is based on the principle that conception and implementation are intimately linked, with a core of common meaning. During the dialogue process, people learn how to think together - not just in the sense of analyzing a shared problem or creating new pieces of shared knowledge, but in the sense of occupying a collective 
sensibility, in which the thoughts, emotions, and resulting actions belong not to one individual, but to all of them together. (1994: 358 [original italics])

During the 20th century, the dialogic philosophy was associated more than all others with its most prominent advocates, such as Martin Buber, Emmanuel Levinas, along with Paulo Freire's critical pedagogy, the humanistic psychology propounded by Carl Rogers, Nel Noddings's pedagogy of care and concern, and even the integrative perspective of Georg Gadamer's hermeneutics.

The concept of the dialogic has become quite challenging as there has been both a growing desire for, as well as, erosion of the dialogic in the last several years. The use of dialogue has become important in teacher education, in general, and in higher education institutions, particularly in their connecting to and collaborating with the field. Indeed, the relationship between academia and the surrounding environment has changed markedly over the last two decades. Massification and diversification of the higher education system, economic globalization, novel modes of knowledge production, new professional requirements, and the establishment of new vocational higher education systems in many countries have challenged higher education institutions to develop new forms of collaboration with working life (Tynjälä, Välimaa and Sarja, 2003).

In writing about Freirian dialogue, Natan Gover (2008: 195-196) stated:

[.... The discussion of dialogue in education is more complicated. Indeed, we might ask, what is the relationship between dialogue and education? After all, the teacher is the one who knows the material that has to be studied and the pupil is assumed to be lacking knowledge. What is there to dialogue about? The teacher teaches the pupil. And, as he or she matures and knows more, then we will see if he or she is interested in dialogue and in what manner. Now, if you insist and still want to undertake an educational dialogue, then what do you mean by this? Does this mean to enable the pupil to ask questions and to answer patiently, while taking into consideration her abilities and her views? Or, perhaps to guide the pupil to discover the knowledge desired by himself? Or, more far reaching, to determine through discussion with the pupil the desired knowledge that he will study? Or, even further, to teach the pupil via discussion only what she wants to study? 


\section{the model in action}

The teacher-education pedagogy presented here is based on two central practical and philosophical axes - dialogue and reflection. These are exemplified in each of the professional learning circles of teacher-training students and their instructors by means of dialogic and reflective discourse communities that operate in parallel and in tandem with the goal of creating links, correlations, and changes in both these circles at the same time. The pedagogy of dialogue and reflection seeks to meet the challenges posed by more extensive usage of dialogue in education by regarding the field of teaching-training as constructed of three parallel and interlinked types of learning-research communities: teacher-trainers, mentors, and teacher-trainees. All of the activities of these communities are interrelated and affect one another.

As part of the vision of the pedagogy of dialogical reflection, communities of multi-cultured students have been established. Including Jews, Arab-Muslim, Arab Christians, Arab Druze, Arab Armenians, and Circassians - reflective of the various groups in Israeli society - these communities are integrated within public schools that teach Hebrew and Arabic. Such participation in a discourse dialogue seeking to concretize the principle of multicultural dialogue around professional learning in the field of teaching, this method allows students to gain teaching experience in an atmosphere of equality and an on-going dialogic discourse between the groups without giving priority to any one national or collective narrative. The groups are also composed of teacher-trainees specializing in various fields - history, civics, language, literature, English, communication, etc. Here, too, the groups constitute diverse and pluralistic professional communities that promote generic dialogic discourse between divergent fields of knowledge with respect to their structure, curriculum, and method of instruction.

The learning day generally begins with a dialogical-reflective group discourse guided by the group leader from the university. The discourse includes all the principles of dialogue and reflection, both formally and substantively. The students raise pedagogic and educational cases they have experienced in their practica, reviewing the dialogue they held with their mentors, the class they 
taught, and their views of the teaching profession. In these meetings which operate as communities of inquiry the students practice the six dimensions of philosophy with children (Kizel, 2016). For example, opinions regarding pedagogy they witnessed and experienced are constructed and issues such organization within the classroom, the order of the meeting, classroom power relations, the school architecture, etc. discussed. Diverse aspects relating to the teacher's classroom leadership and the ability to become agents of change dedicated to reflection, transcendence, and cognitive and political changes in the school reality are also examined openly. Some of the schools are challenging because they are located in middle - or low - class neighborhoods, the features of the student population constituting a key element in the teachers' work and the difficulties they face.

The community of inquiry's session is followed by a period during which the students observe lessons taught by their school mentor. The students then engage in another open discourse with the latter around the subjects that arose in the classroom that posed pedagogic and educational challenges, the mentor sharing his thoughts about his work process and in most cases also allowing room for feedback from the student. The concept of those meeting is mainly openness towards inquiry and less judgmental of performance. Herein, the mentor involves the student in his thoughts and deliberations regarding what had occurred, the practices he had adopted, and his regrets, this process forming a personal example for reflection as part of a revelatory dialogue, the mentor turning from 'knower' to 'hesitator' and even sometimes to 'not-knower'. This reversal of roles gives the student an opportunity to experience, imagine, and envision herself as engaging in such a dialogue when she has become a teacher herself.

During the day, the students also conduct a class, or part of one. This may be a full or half class, a one-on-one lesson with three-five pupils, a group of students working on a project in a specific area or preparing a lesson unit with the help of pupils. They also observe classes taught by their peers, sitting in on the class and then discussing it after with the coordinator and mentor from the 
academic institution. The latter activity contains a reflective dimension in which the students analyze their performance and receive feedback from the mentor, coordinator, and their peers. Many of these feedbacks are based on questioning the practice and not judging it. They also conduct a class dialogue designed to examine their pedagogic, educational, ethical, and philosophical premises and performance in the classroom while observing the mentor (or other teachers), during extra-curricular activities, and their own taking of a class.

Organizational dialogue occurs in a series of circles during the learning day in school. In the first, students observe, as a community of learners, and interview school staff, being made a partner to their difficulties and challenges. In the second, they meet with various school staff, from the principal to subject teachers and practice an open and critical dialogue. The goal of each organizational dialogical circle is to lay emphasis upon the education system's obligations to the new teacher and give her as full access to the professional community as possible in order to enable her to understand the structure, performance, roles, and challenges that face the school and the teacher working as part of a team.

An additional substantive domain of the organizational dialogue of the program is the student-teachers' growing familiarity with the ways in which educational organizations function, from their structure and finances, internal and external actions with the community, as well as the intricacies of functioning amidst multiple constraints. This process requires as an open and expansive a dialogue as is possible between all participants, including members of the school's administrative staff. This includes examination of the school's written curricula, timetable, budget, and assessment methods. While sharing these materials is informative, such dialogue also demonstrates the staff's openness to engage in critique and their self-reflective capacities.

Student-teachers in the Dialogic Teacher Education program also visit and observe other educational organizations that represent other, even oppositional, educational/organizational philosophies; for example, private schools, democratic or anthroposophical schools, home-schooling, religious schools, and so forth. 
Such visits advance comparisons, critique, and examination of various systems of principles and values all of which enable student-teachers to understand the philosophic and organizational debates between these different educational systems. Sanctioning critical viewing establishes the legitimacy needed for conducting open discussion of philosophic issues, fosters doubt in regard to the realm of the taken-for-granted in educational practice, as well as in the organizational and the pedagogical realms. The fundamental philosophical assumptions of these organizations' educational activities are examined thoroughly and demonstrate the organization's openness to discussion with students.

This process also involves participants in discussion of the educational philosophy of each particular school as well as that of the larger urban educational system, in contrast to other educational organizations. This enables the studentteacher to become familiar with them, to raise questions, to share doubts, and to engage in a dialogue guided by ethical concerns that, too, are taught in the program. The dialogic elements are characterized by mutual openness, without taking an educational philosophy for granted or concern for the continuity of an organizational reality.

The students' learning day in the school also includes several elements of the pedagogy of dialogue and the pedagogy of reflection. In many respects, this pedagogy is based on the premise that human beings possess the capacity to change, to be more than we were, and to welcome constant change-one of the key demands of the teaching profession. Teacher-trainee reflection being driven by an ethical commitment to dialogical and reflective work both with their pupils and with the school staff and faculty, it encourages overcoming the perception of man as an object and becoming an educating subject committed to an internal struggle that will prepare them for working towards achieving a reflective lifestyle that seeks social change to strengthen and support the weak (including the student population). One of the elements of the pedagogy of reflection is the understanding that a reflective lifestyle contains within it the yearning for a 
willingness to be flexible-i.e., philosophical motility and lability - and a refusal to be rigid personally and professionally.

The communities of students seeking to establish a broad dialogic culture in the teacher-training programme in order to encourage creativity and self-reflective thinking, they emphasize two dialogic dimensions - dialogic organization and the dialogic classroom - on the basis of Isaacs' (1999) five principles (respect, listen, suspend judgment, free yourself and communicate one's reasoning process). The content relates to dialogue and reflection. Throughout the day of learning at schools, these two axes are highlighted from both a practical and philosophical perspective with the aim of creating teachers who are continually engaged in a classroom dialogue with their students, an organizational dialogue with the school administration and staff, and committed to reflection throughout their work in order to implement the necessary changes, accomplish the desired achievements, and encourage others to act in the same way in order to improve the school as a whole.

The group serves as a safe place that seeks to foster an atmosphere of security by enabling the participants to identify the basic views and concepts underlying the teaching-learning process in an open fashion and by linking the ideas to the school reality, dilemmas, social, environmental, and material problems and the personal/emotional challenges that they will face when they become fully-fledged teachers.

The practices of the school day that center the question of professional practice are quite different from traditional teacher training. First, it breaks the professional hierarchy. Second, it changes the role of the mentor from "knower" to partner in the learning process. Third, it allows for equality between teachers and students in order to enable philosophical professional litigation around practices and dilemmas in an open and reflective way. The content of the learning becomes a "text" for discussion and not a "textbook" for memorization and examination.

These dialogical reflective processes are of great significance in the State of Israel - a nation state characterized by a hierarchical system of centralized 
education that lays stress upon a strict policy of supervision, assessment, and evaluation (Kizel, 2013). This reality affords the reflective discourse philosophical community of teacher-trainee students the opportunity to engage in an open and dialogical discourse of the system's structure, regulation, and methods of supervision. At this early stage, before they have become full-qualified teachers, they can use the community to develop their own views, challenge their presuppositions, and test them in relation to the requirements of the systems both on the philosophic-curriculum and the practical classroom level. The egalitarian community of learners allows their views, thoughts, hopes, and fears regarding their profession and future placements to be taken into consideration at a significant stage in their training while laying emphasis on relevance and diversity of opinion. The 'other' - whomever s/he may be - can thus express his/her views openly and honestly.

The second form of dialogue they conduct during the learning day in schools is an organizational dialogue. In the same way as Slotte (2004) proposes adopting dialogue as a way of strengthening organizational intelligence. Basing his ideas on Bohm $(1992,1996)$ - a physicist who employed the dialogic approach in his scientific work - Slotte argues (2004) that dialogue is a form of philosophic work that can be internalized within an organizational culture and employed in such organizational activities as daily meetings, developmental discussions, workrelated meetings, problem-solving, developing organizational strategies, leadership, and determining an organization's moral vision. Adducing examples from the daily life of leaders, organizations, and employees, he found that staff enjoyed the advantages achieved through such philosophical dialogic endeavours. Dialogue embedded in the organizational culture also improved communication and work relations as well as serving as a basis for problem-solving and the creation of organizational trust.

Manifestations of reflection exist in each of the dialogical and reflective circles of the teacher education program in parallel with the goals of broadening, deepening, and investigating professional thinking reflected in van Manen's 
taxonomies of reflection (1991) - which are based on Dewey's dimensions of the immediate, intuitive day-to-day aspect of reflection and the more distant aspect that enables personal growth in the demand for change. In the pre-reflective stage, guidance is given within the advisors' group, the students' group, and the mentors' group, the school staff also helping the teacher-trainees. In the second stage, the reflection broadens out to include the daily experiences of each of the groups, which thereby receives a voice and forms the basis for conclusions regarding dos and don'ts. In the third stage, the reflection becomes more systematic, no longer being confined to personal experiences but also focusing on the experiences of others (advisors, students, mentors), with the goal of shaping theoretical and critical insights into teaching experiences and organizational performance in the school. In the fourth and final stage, each of the learning community's members reflects on his/her own reflective processes and the way in which s/he constructs theoretical knowledge in order to reach a better understanding of his/her reflection on the nature of knowledge, the ways it works, and how it can be applied in practice.

This process takes place in a workshop setting during the teacher education program, guided by the thoughts of Martin Buber. The foundations of work at the workshop, as well as throughout the teacher education program in Haifa, can be found in essential dialogic constructs elaborated upon in the philosophies of Martin Buber and Emmanuel Levinas. For Buber, encounter (Begegnung) has significance beyond co-presence and individual growth. He looked for ways in which people could engage with one another fully - to meet themselves. The basic fact of human existence was not the individual or the collective as such, but rather for Buber - "Man with Man".

In addition to the concepts of Philosophy with Children focusing on dialogue and reflection, the program's leaders at the University of Haifa adopted the Buberian dialogic method and its conception of dialogic encounters because it is especially relevant today, in regard to the possibilities for teacher education as a way of counter-education, and can become an avenue for enriching a new 
language of Critical Teacher Education Pedagogy. The planners of the program adopted Buber's ideas that the authentic solution to existential loneliness is misframed as being dependent on the choice between collectivism and individualism (Buber, [1938] 1962: 110). In Buber's view, we should be liberated from this Kierkegaardian belief in favor of a third option- the interpersonal path residing in the bond between one person and another. This alternative lies "beyond the subjective, out of the domicile of the objective, on a path along a narrow ridge along which you and I meet, in the in-between" (Ibid: 112).

Buber argued that the real in these thoughts is an extension of the notion of relation beyond inter-human relations to the whole of existence. The dialogic dimension which lays at the center of the teacher education program relates, as well, to the principle of responsibility, as enunciated by Emmanuel Levinas. In his view, as a speaking subject, a person does not place him/herself in the center, but turns to the Other. This attitude of commitment to the Other (in this case - to the teacher-student) must also be expressed in action. This approach is implemented in in the context of teacher education.

The pedagogy of dialogue and reflection in the University of Haifa is tied to Buber and Levinas's ideas, as well as, the philosophy of personal dialogue that may be an instructive method, too, for such ethical inquiry as well as for defining the nature of personal responsibility. It is not a naïve approach, but rather an existential and counter-educative engagement in an era of disaffection, terror, and unfamiliarity.

The dialogical learning process involving the student-teachers and teachers that takes place during the school year is enabling participants to engage in such dialogic exchanges in regard to the organizational nature of educating. Such a dialogic process builds a philosophic community that, as stated by Freire (1970), may stand in opposition to a static, lifeless, fossilized, synthetic reality that is classifiable and predictable. This new educator's community is aiming towards developing an activist dimension given that the dialogic can intensify the need for and value of activism. The hermeneutics of care, even love, is expressed in the 
group's meetings; as modesty, not a sense of superiority, is required in this ongoing creative process. Hope, too, is integrated as participants come to understand one another's foibles, whether it be the student-teacher or the educator.

\section{conclusion}

The pedagogy of dialogue and reflection presented in this article is practiced in the context of the educational dialogue of educators at the pre-service stage of teacher-training is outlined as a tool for student empowerment, achieved through a philosophical community of learners who dedicate space to the developing of their whole personality within the profession, taking a moral stance towards the educational discourse, minimizing judgmentalism and prejudice, creating national/gender equality with the goal of examining the fundamental question of educational performance, and reinforcing their sense of organizational belonging within the system.

This program was practiced during ten-year program of teacher education at the University of Haifa's faculty of education. It was based on pedagogy of dialogue and reflection - a framework that develops and empowers university's students by engaging them in a process of continual improvement responding to diverse situations, providing stimuli for learning, and giving anchors for mediation on the basis of the concepts of Philosophy with Children which were implemented into an adults teacher educations' program. The pedagogy of dialogue and reflection relates, in this case, relates to dialogue not only from a theoretical historical context but also by way of example and it offered empowering dialogues within the traditional teacher-education framework.

The pedagogy of dialogue and reflection is based on the view that reflective dialogue forms one of the best ways in which students' learning needs can be identified and understood, the dialogic partnership between teacher and student facilitating the latter's ability to assess their 'real' level of knowledge and reach and exceed their potential in every stage of the learning process. This pedagogy was employed during the pre-service teacher-education period, students training 
to become school teachers doing their practica in schools in dialogical communities while simultaneously taking university courses to deepen and broaden their theoretical and disciplinary knowledge.

\section{bibliography}

Alrø, H., \& Skovsmose, O. (2004). Dialogue and learning in mathematics education intention, reflection, critique. Dordrecht: Kluwer Academic Publishers.

Bohm, D. (1992). Thought as a System. London: Routledge.

Bohm, D. (1996). On Dialogue. New York: Routledge.

Buber, M. (1938/1962). The Problem of Man: A Philosophical Anthropological Investigation. Jersusalem: Mosad Bialik (Hebrew).

Freire, P. (1970). Pedagogy of the Oppressed. NY: Continuum.

Gadamer, H. G. (1999). Truth and Method. New York: Continuum.

Goodlad, J. I. (1984). A Place Called School. New York: McGraw-Hill.

Goodlad, J. I. (1990). Teachers for Our Nation's Schools. San Francisco: Jossey Bass.

Goodlad, J. I. (1994). Education Renewal: Better Teachers, Better Schools. San Francisco: Jossey Bass.

Gover, N .(2008). The Fereirean dialogue: Empowerment, libaretion, political literacy and social solidarity. In: N. Aloni (Ed.) Empowering Dialogues in Humanistic Education. Tel Aviv: Hakibbutz Hameuchad, pp. 195 - 213 (Hebrew).

Heckmann, G. (1981). Das Sokratische Gesprach: Erfahrungen in Philosophischen Hochschulseminaren. Hannover: H. Schroedel.

Isaacs, W. (1999). Dialogue and the Art of Thinking Together. New York: Doubleday.

Kizel, A. (2013). "Clashing Narratives in Civic Education in Israel." Global Education Review 1 (3), 70-74

Kizel, A. (2016). "Philosophy with Children as an Educational Platform for SelfDetermined Learning." Cogent Education 3 (1), 1244026

<https://doi.org/10.1080/2331186X.2016.1244026>

Kizel, A. (2016a). Pedagogy out of fear of philosophy as a way of pathologizing children. Journal of Unschooling and Alternative Learning, 10(20), 28-47.

Levine, M. (2001). Standards for Professional Development Schools. Washington, DC: National Council for Accreditation of Teacher Education.

Lipman, M., Sharp, A. M., \& Oscanyan, F. S. (1980). Philosophy in the Classroom. Philadelphia: Temple University Press.

Manen, M. van (1991) The Tact of Teaching; The Meaning of Pedagogical Thoughtfulness. Albany: State University of New York Press.

Marshall, H. (1990). Beyond the work place metaphor: The classroom as a learning setting. Theory in Practice, 29, pp. 94-100.

Nelson, L. (1949). Socratic Method and Critical Philosophy: Selected Essays. New Haven: Yale University Press.

Peters, R. S. (1966). Ethics and Education. New York: Scott, Foresman and Company.

Senge, P. (1994). The Fifth Discipline Fieldbook: Strategies and Tools for Building a Learning Organization. New York: Nicholas Brealey.

Shulman, L. S. (1986). Those who understand: Knowledge growth in teaching, Educational Researcher, 15, pp. 4-14.

Sirotnik, K. A. (2001). Renewing Schools and Teacher Education: An Odyssey in Educational Change. Washington, DC: AACTE Pub. 
Slotte, S. (2004). Dialogue and systems intelligence: A work philosophy. In R. P.

Hämäläinen \& E. Saarinen (Eds.), Systems Intelligence: Discovering a Hidden

Competence in Human Action and Organizational Life (pp. 39-55). Helsinki: Helsinki

University of Technology.

Tynjälä, P., Välimaa, J. and Sarja A. (2003). Pedagogical perspectives on the relationships between higher education and working life. Higher Education 46 (2): 147 - 166.

Zilberstein, M., Ben Perez, M., \& Grienfeld, N. (2006). New Trends in Teacher Education Curriculum: Partnership between Colleges and Schools: The Israeli Story. Tel Aviv: Mofet (Hebrew).

received in: 14.08 .2019

approved in: 08.12.2019 